\title{
A Case Report of Ureteral Duplicity Combinated to a Ureteral Bifidity
}

\author{
Hamza Dergamoun", Jihad Lakssir, Ziani Idriss, Hachem Sayegh, Lounis Benslimane, Yassine Nouini
}

Department of Urology A, Ibn Sina Hospital, University of Rabat, Morocco

DOI: $\underline{10.36347 / \text { sasjs.2020.v06i04.001 }}$

| Received: 23.03.2020 | Accepted: 31.03.2020 | Published: 05.04.2020

*Corresponding author: Dergamoun Hamza

Abstract

Case Report

Among all congenital abnormalities, anomalies of urinary tract represent about one quarter in which the incidence of double ureteris rather common (about 1 in 125 or $0.8 \%$ ), whereas a bilateral duplex collecting system is an unusual abnormality. We present a case of a patient with a combination of ureteral duplicity and ureteral bifidity.

Keywords: Duplicity, bifidity, Malformations.

Copyright @ 2020: This is an open-access article distributed under the terms of the Creative Commons Attribution license which permits unrestricted use, distribution, and reproduction in any medium for non-commercial use (NonCommercial, or CC-BY-NC) provided the original author and source are credited.

\section{INTRODUCTION}

Malformations of the urinary system are common and are found in about 3 percent of live births. These various malformations include malrotation, ectopia and other morphological variations such as number of ureters, kidneys. Duplex ureter is one of those malformations, which occurs 1 in 125 cases or $0.8 \%$ of a non-selected population with female to male ratio of $1.6: 1$ or $62 \%$ of females. A duplex ureter may be unilateral or bilateral and it also may be complete or incomplete. The duplication of the ureter is the most common anomaly; however bilateral total duplication is unusual. Patients with this anomaly have an increased risk of hydronephrosis, stone formation, and urinary tract infections. Therefore, considering a rare occurrence of duplication, its embryological significance and clinical implications, we report a case of ureteral duplicity and ureteral bifidity

\section{CASE PRESENTATION}

A 38-year-old married woman has been admitted to our urology department. She has been hospitalized to explore her right low back pain.

A physical examination was normal. Her temperature was $37.3^{\circ} \mathrm{C}$, with a pulse rate at 76 beats per minute and her blood pressure was $130 / 70 \mathrm{mmHg}$. Laboratory tests were normal; in particular, a urine examination showed no bacteriuria or leukocyturia.

She underwent an abdominal ultrasound which showed an asymmetric size of the kidneys with a cute right hydronephrosis.
An abdominal and pelvic computed tomography (CT) scan detected a left completely duplicated collecting system with no hydroureteronephrosis. On the right, an uncomplete duplicated ureter before joining the bladder with hydroureteronephrosis.

The patient was put on medical treatment controlled six months later with an abdominal ultrasound and did not have any medical intervention.

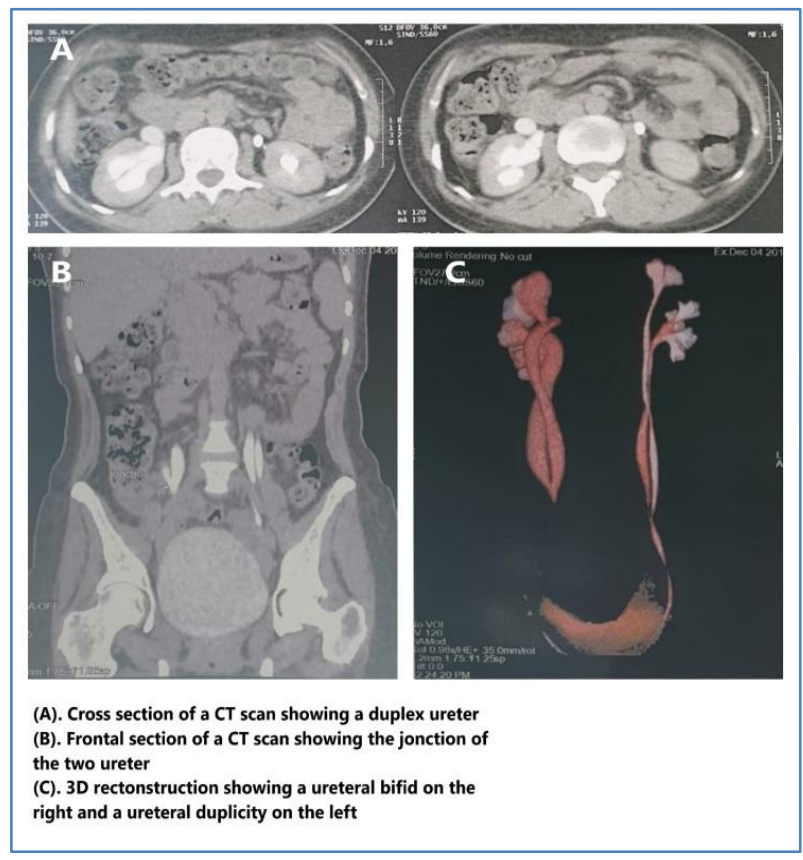




\section{DISCUSSION}

In this case, we present a bilateral duplex collecting system. The limitation of our approach was the duration of the follow-up which is only lasted approximately six months. The discussion will point out the originality of the abnormality.

Bilateral duplex collecting system is an uncommon abnormality. It occurs in 1 in 500 persons and is found in $0.3 \%$ of excretory urograms [1]. Some cases have been reported on bilateral duplex collecting system $[2,3]$. But there are not much data about it. Generally, the cases reported in the literature are mostly related to unilateral duplex collecting system.

According to the Weigert-Meyer law, the upper pole ureter typically opens medially while the lower pole ureter opens laterally. Complete ureteral duplication may be associated with other congenital anomalies such as an upper moiety ureter with an ureterocele causing obstruction ora short lower moiety intramural ureter causing VUR $[1,4]$.

VUR almost always occurs into the lower pole moiety due to its lateral displacement within the bladder [5]. However, the association of bilateral duplex collecting system, bilateral VUR, and refluxing upper pole moiety is not clearly described in the literature to the best of our knowledge.

\section{Conclusion}

Based on the available literature, the present case is very rare. Usually it will be detected at autopsy or as radiological finding but is associated with wide variety of clinical manifestations. Hence the knowledge of which should be borne in mind when dealing with a case of repeated urinary infections, urinary reflux disorders, hydronephrosis or stone formation.

\section{Competing interests}

The authors declare no conflict of interest.

\section{Authors' contributions}

All the authors have read and agreed to the final manuscript

\section{REFERENCES}

1. Schlussel RN, Retik AB. Ectopic ureter, ureterocele and other anomalies of ureter. In: Wein A, Novick AC, Kavoussi LR, Partin AW, Peters CA, editors. Campbell-Walsh urology. 9th ed. Philadelphia: Saunders Elsevier. 2007; 3383-422.

2. Keskin S, Erdoğan N, Kurt A, Tan S, İpek A. Bilateral partial ureteral duplication with double collecting system in horseshoe kidney. Adv Med Sci. 2009;54(2):302-4.

3. Afzal U, Al-Shammari RM, Siraj QH, Hebbar S. A case of dupable duple duplicity and duplexity. Asia Ocean J Nucl Med Biol. 2013;1(2):53-5.

4. Hunziker M, Mohanan N, Puri P. Dextranomer/Hyaluronic acid endoscopic injection is effective in the treatment of intermediate and high grade vesicoureteral reflux in patients with complete duplex systems. J Urol. 2013;189:187681.

5. Thomas JC. Vesicoureteral Reflux and Duplex Systems. AdvUrol. 2008;2008:651891. 